\title{
Comparative Analysis of Site Preparation Costs of Poplar Plantations Establishment by Various Technological Schemes
}

\author{
Konstantin Marinov and Velika Jordanova \\ Faculty of Forestry, University of Forestry, Sofia 1797, Bulgaria
}

\begin{abstract}
In this work, the costs for machinery and all means for site preparation of forest clearings for afforestation with intensive poplar plantations were studied by applying various technological schemes. For this purpose, three technological schemes $\left(\mathrm{TS}_{1}, \mathrm{TS}_{2}\right.$ and $\mathrm{TS}_{3}$ ), applying in Bulgaria, were studied. By applying the respective technological scheme, the site preparation was performed entirely with a milling aggregate PT-400, equipped with multifunctional forest tiller FAE-300/S. The processes of shredding stumps, mulching clearing debris and bushes, and primary tillage of the soil up to depth of $50 \mathrm{~cm}$ were examined. The survey was conducted in poplar clearings along the river Danube, over alluvial moderately moist soil. A new categorization of the poplar clearings is proposed depending on the operating conditions. The performance of the milling unit and the relative costs for labor, machinery and means for site preparation per unit area were defined. Depending on the category of poplar clearings, total cost for site preparation applying the studied technology vary between $27.6 \mathrm{~h} / \mathrm{ha}$ and $29.3 \mathrm{~h} / \mathrm{ha}$, which at current prices of $53.5 € / \mathrm{h}$ for the operation of PT-400 with FAE $300 / \mathrm{S}$ is between $€ 1,478 / \mathrm{ha}$ and $€ 1,569 /$ ha. To conduct comparative analysis of the new technology and the old technologies under similar operating conditions, the relatively costs for site preparation of the previously applied technologies which use rotary and tooth uprooter machines are defined. According to the applied technological scheme and used machines in different categories, clearings costs for land preparation vary between $€ 1,230 /$ ha and $€ 3,300 /$ ha. Based on comparative analysis, it is designed a new technological scheme for afforestation with poplar plantations in riverside clearings, where by ensuring high quality work, the costs for site preparation become lower (24.2-25.9 h/ha) and thus cost from $€ 993 / \mathrm{ha} \mathrm{to} € 1,084 / \mathrm{ha}$ is achieved.
\end{abstract}

Key words: Forest plantations, afforestation, technological scheme for site preparation, costs, forest machinery.

\section{Introduction}

The management of polar plantations requires recovery of the wood space [1-4]. Site preparation for reforestation is the most labor-intensive activity in poplar cultivation [5-8]. The application of more intensive agro-technical practices is of great importance for improving the productivity of poplar plantations. Such agro-technical practices are possible only with complete removal of stumps and wood residues. This requires a large part of capital expenditure to be invested in the first year of the establishment of a new plantation. The introduction of modern machinery and technology for site preparation

Corresponding author: Konstantin Marinov, associated professor, research fields: technologies and mechanizations in forestry, and forest machinery. for reforestation is an important factor for reducing labor costs [9-11]. According to the applied technology and operating conditions, these costs can range from $€ 1,200 /$ ha to $€ 3,500 /$ ha [12-14]. The technological schemes for site preparation for poplar plantations establishment are based on using a particular system of machines. In many cases, the implementation of a scheme and a system of machines depends on the available equipment of the executive firms. Recently, in Bulgarian Northwest Forestry Enterprise, "Vratza" invested in specialized equipment Prime Tech PT-400 with multifunctional forestry tiller FAE 300/S-225 for site preparation [15]. These types of machines have extensive technological capabilities [16-18].

The multifunctional forestry tiller FAE 300/S can perform several operations, which were previously 
performed by three different machines: (1) forestry brush-cutter, (2) milling machine for crushing stumps and (3) tiller for deep subsoiling. The results of the first conducted studies with these machines showed high environmental and quality indicators, and significantly shortened the period for site preparation of the area for afforestation $[11,18]$.

The purpose of the study was to analyze the costs for site preparation for poplar plantations establishment applying various technological schemes.

\section{Materials and Methods}

Three technological schemes built on different systems of machines were used for poplar clearings site preparation to compare the cost of labor and machinery. Because operating conditions in poplar clearings can be very diverse, to obtain the correct results, it is necessary to differentiate these conditions. For this purpose, according to the available wood residues and standing vegetation, clearings are divided into four categories:

(1) Category $1\left(\mathrm{C}_{1}\right)$ : here are included clearings, which have been cleaned from debris and wood residues and which have low standing shrub vegetation not higher of $2 \mathrm{~m}$;

(2) Category $2\left(\mathrm{C}_{2}\right)$ : these clearings are cleaned from debris and wood residues, but have higher vegetation consisting of sprouts, amorphous and shrubs higher than $2.5 \mathrm{~m}$;

(3) Category $3\left(\mathrm{C}_{3}\right)$ : here clearings were not cleaned from residues, although the shrubbery is not higher than $2 \mathrm{~m}$;

(4) Category $4\left(\mathrm{C}_{4}\right)$ : include clearings, not cleaned from wood debris and have high standing vegetation sprouts, amorphous and shrubs higher than $2.5 \mathrm{~m}$.

\subsection{Technological Schemes and System Machines}

\subsubsection{First Technological Scheme $\left(\mathrm{TS}_{1}\right)$}

This is the oldest technological scheme, but still widely applied in Bulgaria for site preparation. It is based on the usage of frontal eradicators for extracting stumps. It contains seven different technological operations and system machines, which uses crawler tractors for aggregation (from $60 \mathrm{kN}$ to $100 \mathrm{kN}$ towing force). According to the category of the clearing, the site preparation includes the following operations and system machines:

(1) Cleaning $\mathrm{C}_{1}$ clearings from vegetation with bulldozer unit, consisting of universal bulldozer DZ-38 and T-170 crawler tractor;

(2) Cleaning $\mathrm{C}_{2}$ clearings of vegetation with bulldozer unit, consisting of universal bulldozer DZ-38 and T-170 crawler tractor;

(3) Cleaning $\mathrm{C}_{3}$ clearings of twigs, wood residues and vegetation with a bulldozer unit, consisting of universal bulldozer DZ-38 and T-170 crawler;

(4) Cleaning $\mathrm{C}_{4}$ clearings of twigs, wood residues and vegetation with a bulldozer unit, consisting of universal bulldozer DZ-38 and T-170 crawler;

(5) Eradicating stumps and roots in the clearings of all categories with eradicating aggregate, consisting of front tooth uprooter D-513 A and T-170 tractor;

(6) Shoving out eradicated stumps from clearings of all categories with bulldozer unit, consisting of frontal bulldozer DZ-27 and T-170 tractor;

(7) Alignment after eradication in all categories clearings with aggregate, consisting of universal bulldozer DZ-38 and T-170 tractor;

(8) Main tillage up to $50 \mathrm{~cm}$ in clean clearings from all categories with plough unit, consisting of plough for deep plowing PPN-50 or PPU-50 and T-170 tractor;

(9) Alignment after plowing the clearings of all categories with leveling unit, consisting of universal bulldozer DZ-38 or leveling beam NG-4 and T-170 tractor.

\subsubsection{Second Technological Scheme $\left(\mathrm{TS}_{2}\right)$}

This technological scheme is implemented in the country since 1980s. It is built on the basis of specialized rotary eradicators for crushing stumps. The propulsion uses tractors with power $80-120 \mathrm{~kW}$. The system of machines for cleaning clearings and primary 
tillage is similar to the first technological scheme. At different clearings, the site preparation applying this scheme includes the following operations and machines:

(1) Cleaning $C_{1}$ clearings from vegetation with bulldozer unit, consisting of universal bulldozer DZ-38 and crawler tractor T-170;

(2) Cleaning $\mathrm{C}_{2}$ clearings of vegetation with bulldozer unit, consisting of universal bulldozer DZ-38 and $\mathrm{T}-170$ tractor;

(3) Cleaning $\mathrm{C}_{3}$ clearings of twigs, wood residues and vegetation with a bulldozer unit, consisting of universal bulldozer DZ-38 and T-170 tractor;

(4) Cleaning $\mathrm{C}_{4}$ clearings of twigs, wood residues and vegetation with a bulldozer unit, consisting of universal bulldozer DZ-38 and T-170 tractor;

(5) Shredding stumps and roots in the clearings of all categories with rotary eradicator Rotor Speedy 130/160;

(6) Main tillage up to $50 \mathrm{~cm}$ in clean clearings from all categories with plough unit, consisting of plow for deep plowing PP-50 or PPU-50 and T-170 tractor,

(7) Alignment after deep plowing in clearings of all categories with leveling aggregate, by universal bulldozer DZ-38 or aligning beam PG-4.0 and tractor $\mathrm{T}-170$.

\subsubsection{Third Technological Scheme $\left(\mathrm{TS}_{3}\right)$}

This is the latest scheme for site preparation in Bulgaria, implemented since 2013 in North-West Forestry "Vratza". It is based on new forest tiller (subsoiller) FAE 300/S, powered by a prime mover PT-400. This scheme includes three basic operations that are performed only by one machine: (1) mulching standing tree and sprouts, shrubs and wood debris; (2) shredding stumps; (3) main tillage - subsoiling. For the reduction of auxiliary and non-operating moves and to increase the productivity of the machine, the first two operations can be performed in one stroke as a combined operation, i.e., mulching. The main requirement for this operation is the available lying and standing vegetation to be shredded into large splinters (chunks) with a length of $2.5-7.5 \mathrm{~cm}$. The main treatment of the soil can be carried out immediately after that, as a second stroke or separately, after preparation of the entire area. To facilitate the study, operations of $\mathrm{TS}_{1}, \mathrm{TS}_{2}$ and $\mathrm{TS}_{3}$ are performed separately. The site preparation in $\mathrm{TS}_{3}$ comprises the following steps:

(1) Crushing standing vegetation in $\mathrm{C}_{1}$ clearings by forest unit PT-400 with multipurpose forestry tiller FAE 300/S;

(2) Crushing standing vegetation in $\mathrm{C}_{2}$ clearings by forest milling unit PT-400 aggregated with tiller FAE 300/S;

(3) Shredding of wood residues, brushes and standing vegetation in $\mathrm{C}_{3}$ clearings, by forest milling unit PT-400 with tiller FAE 300/S;

(4) Shredding of wood residues, brushes and standing vegetation in $\mathrm{C}_{4}$ clearings, by forest milling unit PT-400 with tiller FAE 300/S;

(5) Shredding stumps in clearings of all categories, by forest milling unit PT-400 with tiller FAE 300/S;

(6) Primary soil cultivation after eradication of clearings from all categories by deep tilling up to 50 $\mathrm{cm}$, by milling aggregator PT-400 with tiller FAE $300 / \mathrm{S}$.

The examined machines for all the schemes are:

(1) Mulching unit-forestry tiller FAE 300/S-225, driven by PT-400, with power of $310 \mathrm{~kW}$ (Fig. 1a);

(2) Eradicating unit-front-tooth eradicator D-513A with crawler T-170, with a tow class $100 \mathrm{kN}$ (Fig. 1b);

(3) Eradicating unit-rotary eradicator "Rotor Speedy" 130/160 with wheeled tractor New Holland TM-150, with power $112 \mathrm{~kW}$ (Fig. 1c);

(4) Bulldozer unit - universal bulldozer DZ-38 with crawler tractor T-170 (Fig. 1d);

(5) Tilling unit for deep processing - forestry tiller FAE 300/S-225, driven by PT-400 (Fig. 1e);

(6) Plowing unit for deep processing-plough PP-50, driven by crawler tractor T-170 (Fig. 1f);

(7) Alignment unit—bulldozer DZ-38 or leveling beam PG-4, driven by crawler tractor T-170. 


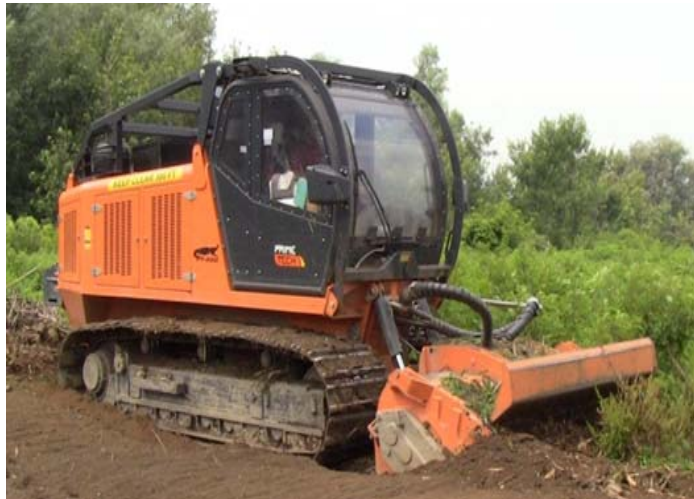

(a) Mulching unit-multifunctional forestry tiller FAE $300 / \mathrm{S}-225$ driven by prime mover PT-400.

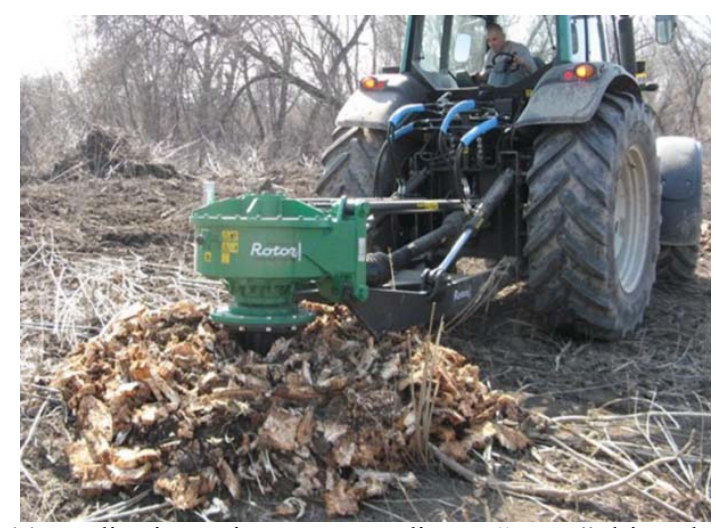

(c) Eradicating unit-rotary eradicator "Rotor" driven by wheeled tractor New Holland TM-155.

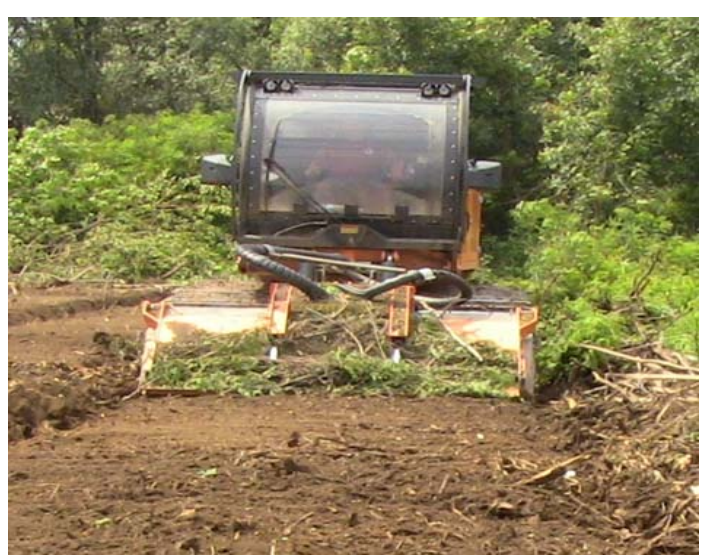

(e) Aggregate for deep milling - forestry tiller FAE $300 / \mathrm{S}-225$, driven by prime mover PT-400.

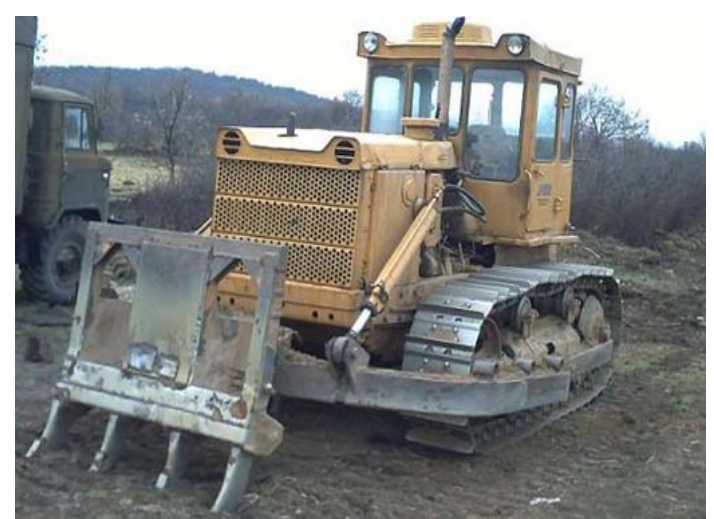

(b) Uprooted unit-front-tooth eradicator D-513A driven by crawler tractor $\mathrm{T}-170$.

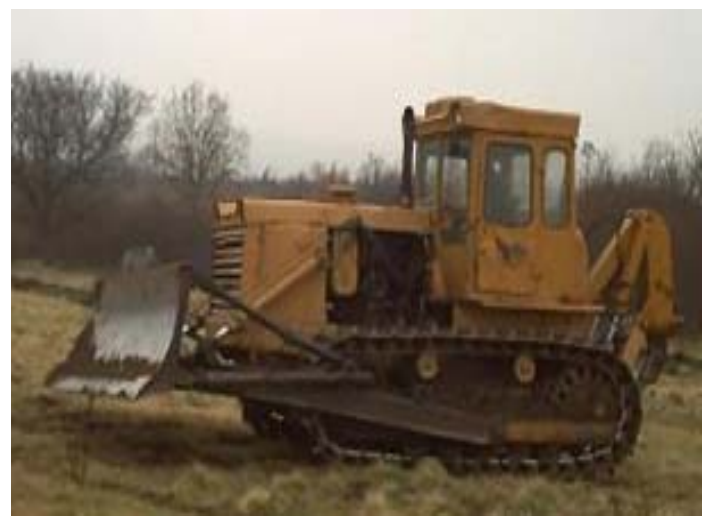

(d) Bulldozers unit — universal bulldozer DZ-38 driven by crawler tractor $\mathrm{T}-170$.

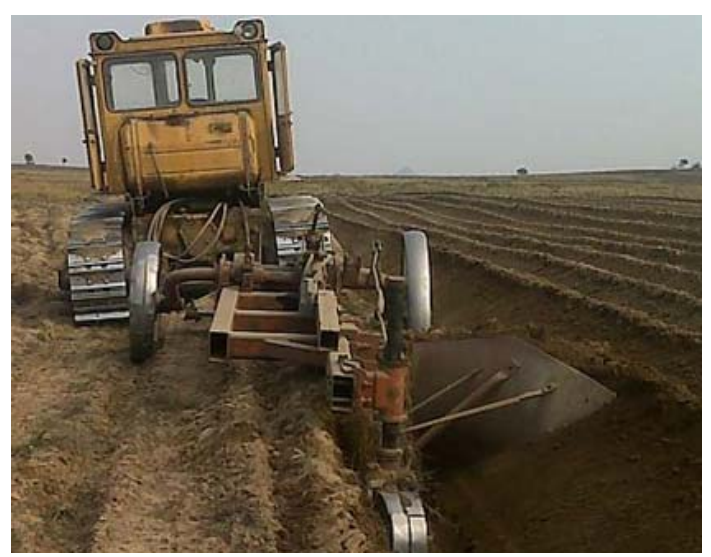

(f) Plowing unit—plough PP-50 driven by crawler T-170.

Fig. 1 Machines used in ground and site preparation for the technological schemes.

\subsection{Study Place and Condition}

The survey was conducted in poplar clearings along the Danube River, which is derived $100 \%$ logging. The afforestation is carried out with one or two-year poplar saplings. To conduct the study, several experimental plots were bet within working area of
52.5 ha. The density of the stumps in the clearing is 62 pcs per ha. The average diameter of the stumps is 40.2 $\mathrm{cm}$ (ranging from $28 \mathrm{~cm}$ to $55 \mathrm{~cm}$ ). The soil is alluvial, very deep and non-rocky. The terrain is flat, with altitude $250 \mathrm{~m}$. The clearing and the experimental plots have rectangular shaping, which favors the 
movement and operational moves of the machines. The habitat type is M-I-1, $\mathrm{D}_{2,3}$ [19]. Moesian forest-plant area of floodplain and riparian forests in Bulgaria is at an altitude of 0 to $600 \mathrm{~m}$. The average float duration is from one to two months. The lands are located at +2 and +3 meters above the isometric line of Danube river middle level. These habitats are suitable for growing Euro-Americans poplar clones.

The measuring equipment consists of: tape measure and GPS system "Speed Data TT-43" for measuring the volume of field work; stopwatch to determine the duration of operations; spring penetrometer "DickeyJohn" to determine the hardness of the soil; altimeter "Vertex IV" to measure tilt; analytical balance "Sartorius ME235S" to measure the weight of the samples with an accuracy of $0.01 \mathrm{~g}$. The soil moisture is determined by weight method by drying samples in a thermostatic cabinet at temperature $T=103 \pm 2{ }^{\circ} \mathrm{C}$.

During the study was carried out site preparation within three experimental areas, covering 20 ha. In each of them were bet total amount of 27 sample plots with a length of $100 \mathrm{~m}$ and a width of $2.5 \mathrm{~m}$. Both operators of the milling unit FAE 300/S were experienced.

\subsection{Experimental Parameters}

To establish the expenditure of time and the productivity of the milling unit PT-400 for the operations of mulching, shredding stumps and deep milling, some experimental observations were carried out with pre-defined input and output factors.

\subsubsection{Input Factors}

These input factors are related to working conditions and can not be managed during the experiments, but can be maintained at the same level: slope $-2^{\circ}$; average diameter of stumps $d=0.4 \mathrm{~m}$; scheme of the plantation rows before felling $(4 \mathrm{~m} \times 4$ $\mathrm{m})$ and density of the stumps - $62 \mathrm{pcs} / \mathrm{ha}$; depth of the tillage $-50 \mathrm{~cm}$; length of the working range $-100 \mathrm{~m}$; mechanical structure and category of the soil-sandy-clay; soil moisture-30\% to $33 \%$; hardness of the soil- $1.95 \mathrm{MPa}$.

These production conditions are characteristic of floodplain areas and areas along the Danube River. Such areas are appropriate for afforestation with intensive poplar plantations. The speed of the drive engine PT-400 and the rotational speed of the working bodies of the cutter $300 \mathrm{FAE} / \mathrm{S}$ are input controllable factors, which can be managed and maintained at the same level. From the previous studies [11, 18] in similar field conditions, it was found that good production results are obtained under the following operating speeds:

(1) Mulching: by the working speed at 2nd gear of PT-400 and speed of 500 revolutions/min for the milling drum of FAE $300 / \mathrm{S}$;

(2) Shredding stumps: by 500 revolutions/min of rotation rate of the milling drum of FAE 300/S;

(3) Deep milling: by the working speed at 1 st or 2nd gear of PT-400, and 375-500 revolutions/min of rotation rate of the milling drum FAE 300/S.

\subsubsection{Output Parameters}

The output parameters, which can be measured and used to determining the time consumption and the performance of the milling aggregate, are duration of the operations and volume of the performed work.

The volume of the performed work was measured after each experimental observation. To measure the expenditure of time for the different operations, timing observations and records were made. The expenditure of operating time and productivity were determined by pre-approved methods for standardization and exploitation of machine-tractor units for afforestation activities in Bulgaria [20]. The performance and the time spent for the different operations, when using the other technological schemes for the same production conditions were determined on the basis of data received from the previous studies [9] and the established norms for Republic of Bulgaria [21, 22].

\section{Results and Discussion}

At the beginning of the study, one of the operators 
tried to keep more intensive and highly crushed the remaining wood chips (up to $2 \mathrm{~cm}$ ), which led to greater expenditure of time. Later, with the advancement of research, this aspiration was gradually overcome and began the producing of wood fractions with normal size from $2.5 \mathrm{~cm}$ to $7.5 \mathrm{~cm}$. The average values of the measured times of the observed activities and the extent of the use of working time are given in Table 1. The level of machinery operating time within a shift is expressed by the factor of working time $\tau_{s h}$. It is defined as the ratio between the operating time at working stroke of machines $\left(t_{s t}\right)$ and the full time duration of shift $\left(t_{s h}\right)$, as Eq. (1):

$$
\tau_{s h}=t_{s t} / t_{s h}
$$

The results showed a higher level of utilization of the working time at a primary tillage of the soil. This is due to the correct configuration of the terrain and less time needed aggregate to maneuvers. For mulching and crushing stumps, more non-operating times are needed for maneuver. This fact is more visible at shredding larger stumps, where depending on their diameters, the needed strokes (forward and backward) were between four and six. Other nonproductive times and stands were relatively minimal. This is due to the good organization of the work process, the high technical reliability of the machine and expert qualifications of the workers. The times for services $\left(t_{s e}\right)$ and preparatory-final activities $\left(t_{p-f}\right)$ were part of daily technical exploitation of the machines $\left(t_{s e}\right.$ $=15-20 \mathrm{~min}$, and $t_{p-f}=30-35 \mathrm{~min}$ ). Eventually, after determining the times for every operation and establishing the total work by direct measurement of the treated area, performance was determined, under the certain conditions. Based on this were established the labor and machinery costs for site preparation in hours per hectare $(\mathrm{h} / \mathrm{ha})$.

Table 1 Observed time of machine activity within a shift.

\begin{tabular}{|c|c|c|c|}
\hline Observed time (min) & $\begin{array}{l}\text { 1st section: } \\
\text { mulching of sprouts, brushes and debris }\end{array}$ & $\begin{array}{l}\text { 2nd section: } \\
\text { crushing stumps }\end{array}$ & $\begin{array}{l}\text { 3rd section: } \\
\text { deep milling of the soil }\end{array}$ \\
\hline Operating time at working stroke $\left(t_{s t}\right)$ & 364 & 356 & 380 \\
\hline Idle time $\left(t_{i}\right)$ & 45 & 51 & 29 \\
\hline Operational time $\left(t_{o}\right)$ & 409 & 407 & 409 \\
\hline Preparatory-final time $\left(t_{p-f}\right)$ & 32 & 32 & 31 \\
\hline Service time $\left(t_{s e}\right)$ & 16 & 17 & 16 \\
\hline Rest time $\left(t_{r}\right)$ & 20 & 20 & 20 \\
\hline Administrative time $\left(t_{a}\right)$ & 3 & 4 & 4 \\
\hline Delays $\left(t_{d}\right)$ & 71 & 73 & 71 \\
\hline Total time of shift $\left(t_{s h}\right)$ & 480 & 480 & 480 \\
\hline Level of working time $\left(\tau_{s h}\right)$ & 0.758 & 0.742 & 0.785 \\
\hline
\end{tabular}

Table 2 Performance and expenditure of time by operations in $\mathrm{TS}_{1}$.

\begin{tabular}{llll}
\hline No. & Technological operation & $\begin{array}{l}\text { Performance for a } \\
\text { shift (ha/shift) }\end{array}$ & $\begin{array}{l}\text { Cost of machinery } \\
\text { and labor (h/ha) }\end{array}$ \\
\hline 1 & ${\text { Cleaning } C_{1} \text { clearings from vegetation with bulldozer unit }}_{2}$ & 0.690 & 11.6 \\
2 & ${\text { Cleaning } \mathrm{C}_{2} \text { clearings of vegetation with bulldozer unit }}$ & 0.584 & 13.7 \\
3 & $\begin{array}{l}\text { Cleaning } \mathrm{C}_{3} \text { clearings of twigs, wood residues and low stand vegetation with a } \\
\text { bulldozer unit }\end{array}$ & 0.358 & 22.3 \\
& $\begin{array}{l}\text { Cleaning } \mathrm{C}_{4} \text { clearings of twigs, wood residues and high stand vegetation with a } \\
\text { bulldozer unit }\end{array}$ & 0.328 & 24.4 \\
5 & Eradicating stumps and roots in the clearings of all categories with tooth eradicator & 0.210 & 38.1 \\
6 & Shoving out eradicated stumps from clearings with bulldozer unit (all categories) & 0.443 & 18.1 \\
7 & Alignment after eradication in all categories clearings (all categories) & 0.672 & 11.9 \\
8 & Main tillage up to 50 cm in clean clearings with plough unit (all categories) & 0.588 & 13.6 \\
9 & Alignment after plowing the clearings (all categories) & $4.444^{*}$ & $1.8^{*}$ \\
\hline
\end{tabular}

* Alignment with PG-4. 
Table 3 Manufacturing costs for site preparation of poplar clearings in $\mathrm{TS}_{1}$.

\begin{tabular}{lll}
\hline Category of poplar clearings & Summary relative cost of machinery and labor $(\mathrm{h} / \mathrm{ha})$ & ${\text { Price per ha of site preparation }(€ / \text { ha })^{* *}}^{*}$ \\
\hline $\mathrm{C}_{1}$ & 95.1 & $2,910.1$ \\
$\mathrm{C}_{2}$ & 97.2 & $2,974.3$ \\
$\mathrm{C}_{3}$ & 105.8 & $3,237.5$ \\
$\mathrm{C}_{4}$ & 107.9 & $3,301.7$ \\
\hline
\end{tabular}

${ }^{* * *}$ The price of $1 \mathrm{~h}$ machine work includes all production costs, material costs (fuel and lubricants, maintenance, repair and spare parts, transport, etc.), salaries, insurances, maintenance, profit and others.

\subsection{Cost in $T S_{1}$}

The obtained average values for productivity and machinery costs in $\mathrm{TS}_{1}$ are presented in Table 2 for every operation. The obtained results show that the productivity of cleaning clearings varies widely depending of the clearing category. It reduces almost double from $0.69 \mathrm{ha} / \mathrm{shift}$ for $\mathrm{C}_{1}$ to 0.328 for $\mathrm{C}_{4}$. At the same time, labor and machinery costs increase almost twice, from $11.6 \mathrm{~h} / \mathrm{ha}$ to $24.4 \mathrm{~h} / \mathrm{ha}$. These results confirm once again the need for cuttings categorization. The relative costs of labour and machinery in $\mathrm{TS}_{1}$ is the highest.

Total relative costs of labor and machinery and average price per ha of mechanized site preparation, applying $\mathrm{TS}_{1}$, are provided in Table 3 .

For $\mathrm{C}_{1}$ clearings, operations No. 1, 5, 6, 7, 8 and 9 are carried out in accordance with Table 2. The total relative costs for labor and machinery for site preparation of 1 ha is $H=95.1 \mathrm{~h} / \mathrm{ha}$. At a minimum price of $€ 30.6 / 1 \mathrm{~h}$ for operation with crawler T-170 with detachable equipment, the average cost of 1 ha site preparation is equal to $€ 2,910.1 / \mathrm{ha}$.

For $\mathrm{C}_{2}$ clearings, operations No. 2, 5, 6, 7, 8 and 9 are carried out in accordance with Table 2 . The total relative cost of labor and machinery for site preparation of 1 ha is $H=97.2 \mathrm{~h} / \mathrm{ha}$. At a minimum price of $€ 30.6 / \mathrm{h}$ for the operation of tractor T-170 with detachable equipment, the average cost per ha site preparation is $€ 2,973.3 / \mathrm{ha}$.

For $\mathrm{C}_{3}$ clearings, operations No. 3, 5, 6, 7, 8 and 9 are carried out in accordance with Table 2 . The total relative costs for labor and machinery for site preparation of 1 ha is $H=105.8 \mathrm{~h} / \mathrm{ha}$. At a minimum price of $€ 30.6 / \mathrm{h}$ for the operation of tractor T-170 with detachable equipment, the average cost per ha site preparation is $€ 3,237.5 / \mathrm{ha}$.

For $\mathrm{C}_{4}$ clearings, operations No. 4, 5, 6, 7, 8 and 9 are carried out in accordance with Table 2 . The total relative costs for labor and machinery for site preparation of 1 ha is $H=107.9 \mathrm{~h} / \mathrm{ha}$. At a minimum price of $€ 30.6 / \mathrm{h}$ for the operation of tractor T-170 with detachable equipment, the average cost per ha site preparation is $€ 3301.7 / \mathrm{ha}$.

\subsection{Cost in $T S_{2}$}

The obtained average values for productivity and machinery costs for $\mathrm{TS}_{2}$ are presented for every operation in Table 4. The obtained results show that costs of labour and machinery for removing stumps from area in this technological scheme is $13.2 \mathrm{~h} / \mathrm{ha}$. These costs are $24.9 \mathrm{~h} / \mathrm{ha}$ less, compared to $\mathrm{TS}_{1}$, and $3.4 \mathrm{~h} / \mathrm{ha}$ less, compared to $\mathrm{TS}_{3}$. The costs for the other operations are the same as the first scheme $\mathrm{TS}_{1}$.

Total relative costs of labor and machinery and average price per ha of mechanized site preparation, applying $\mathrm{TS}_{2}$, are provided in Table 5 .

For $\mathrm{C}_{1}$ clearings, operations No. 1, 5, 6 and 7 are carried out in accordance with Table 4. The total relative costs for labor and machinery for site preparation of 1 ha is $H=40.2 \mathrm{~h} / \mathrm{ha}$. At an average price of $€ 30.6 / \mathrm{h}$ for the operation of tractor New Holland TM-155 to stamping machine Rotor Speedy $130 / 160$ and at a minimum price of $€ 30.6 / \mathrm{h}$ for use with T-170 tractor with bulldozer and leveling machines, the cost of 1 ha site preparation is $€ 1,230.1 / \mathrm{ha}$.

For $\mathrm{C}_{2}$ clearings, operations No. 2, 5, 6 and 7 are carried out in accordance with Table 4. The total relative costs for labor and machinery for site 
preparation of 1 ha is $H=42.3 \mathrm{~h} / \mathrm{ha}$. At an average price of $€ 30 / \mathrm{h}$ for the operation of tractor New Holland TM-155 aggregated to eradicating machine Rotor Speedy 130/160 and at a minimum price of $€ 30.6 / \mathrm{h}$ for use with $\mathrm{T}-170$ tractor with bulldozer and leveling machines, the average cost per ha site preparation is $€ 1,294$.4/ha.

For $\mathrm{C}_{3}$ clearings, operations No. 3, 5, 6 and 7 are carried out in accordance with Table 4. The total relative costs for labor and machinery for site preparation of 1 ha is $H=50.9 \mathrm{~h} / \mathrm{ha}$. At an average price of $€ 30.6 / \mathrm{h}$ for the operation of tractor New Holland TM-155 aggregated to eradicating machine Rotor Speedy and at a minimum price of $€ 30.6 / \mathrm{h}$ for use with T-170 tractor with bulldozer and leveling machines, the average cost per ha site preparation is $€ 1,557.5 /$ ha.

For $\mathrm{C}_{4}$ clearings, operations No. 4, 5, 6 and 7 are carried out in accordance with Table 4 . The total relative costs for labor and machinery for site preparation of 1 ha is $H=53.0 \mathrm{~h} / \mathrm{ha}$. At an average price of $€ 30.6 / \mathrm{h}$ for the operation of tractor New Holland TM-155 aggregated to eradicating machine Rotor Speedy and at a minimum price of $€ 30.6 / \mathrm{h}$ for use with T-170 tractor with bulldozer and leveling machines, the average cost per ha site preparation is $€ 1,621.8 /$ ha.

\subsection{Cost in $\mathrm{TS}_{3}$}

The values obtained for productivity and costs of labor and machines in separate operations for $\mathrm{TS}_{3}$ are presented in Table 6 . The results obtained show that labour and machinery total costs in this scheme are the lowest. They are about 1.46 times less than $\mathrm{TS}_{2}$ and 3.45 times less than $\mathrm{TS}_{1}$. This is mainly due to the use of a forestry multifunctional milling machine FAE 300/S (mulcher and tiller) for crushing and shredding of wood residues, brushes and standing vegetation (mulching), and deep soil milling.

Total relative costs of labor and machinery and average price per ha of mechanized site preparation, applying $\mathrm{TS}_{3}$, are provided in Table 7 .

For $\mathrm{C}_{1}$ clearings, operations No. 1,5 and 6 are carried out in accordance with Table 6 . The total relative costs for labor and machinery for site preparation is $H=27.6 \mathrm{~h} / \mathrm{ha}$. At an average cost of about $€ 53.55 / \mathrm{h}$ milling unit PT-400 FAE $300 / \mathrm{S}$, the average cost per ha site preparation is $€ 1,478 / \mathrm{ha}$.

Table 4 Performance and expenditure of time by operations in $\mathrm{TS}_{2}$.

\begin{tabular}{llll}
\hline No. & Technological operation & $\begin{array}{l}\text { Performance for a } \\
\text { shift (ha/shift) }\end{array}$ & $\begin{array}{l}\text { Cost of machinery } \\
\text { and labor (h/ha) }\end{array}$ \\
\hline 1 & Cleaning $C_{1}$ clearings from low vegetation with bulldozer unit & 0.690 & 11.6 \\
2 & Cleaning $C_{2}$ clearings of high vegetation with bulldozer unit & 0.584 & 13.7 \\
3 & Cleaning $C_{3}$ clearings of twigs, wood residues and vegetation with a bulldozer unit & 0.358 & 22.3 \\
4 & Cleaning C 4 clearings of twigs, wood residues and vegetation with a bulldozer unit & 0.328 & 24.4 \\
5 & Shredding stumps and roots in the clearings with rotary eradicator (all categories) & 0.608 & 13.2 \\
6 & Deep tillage up to 50 cm in clean clearings with plowing unit (all categories) & 0.588 & 13.6 \\
7 & Alignment after deep plowing in clearings (all categories) & $4.444^{*}$ & $1.8^{*}$ \\
\hline
\end{tabular}

* Alignment with PG-4.

Table 5 Manufacturing costs for site preparation of poplar clearings in $\mathrm{TS}_{2}$.

\begin{tabular}{lll}
\hline Category of poplar clearings & Summary relative cost of machinery and labor $(\mathrm{h} / \mathrm{ha})$ & Price per ha of site preparation $(€ / \text { ha })^{* *}$ \\
\hline $\mathrm{C}_{1}$ & 40.2 & $1,230.1$ \\
$\mathrm{C}_{2}$ & 42.3 & $1,294.4$ \\
$\mathrm{C}_{3}$ & 50.9 & $1,557.5$ \\
$\mathrm{C}_{4}$ & 53.0 & $1,621.8$ \\
\hline
\end{tabular}

${ }^{* *}$ The price of $1 \mathrm{~h}$ of machine work includes all production costs, material costs (fuel and lubricants, maintenance, repair and spare parts, transport, etc.), salaries, insurances, maintenance, profit and others. 
For $\mathrm{C}_{2}$ clearings, operations No. 2, 5 and 6 are carried out in accordance with Table 6 . The total relative costs for labor and machinery for site preparation of 1 ha is $H=27.9 \mathrm{~h} / \mathrm{ha}$. At an average cost of about $€ 53.55 / \mathrm{h}$ milling unit PT-400 FAE 300/S, the average cost per ha is $€ 1,494.1 / \mathrm{ha}$.

For $\mathrm{C}_{3}$ clearings, operations No. 3, 5 and 6 are carried out in accordance with Table 6 . The total relative costs for labor and machinery for site preparation of 1 ha is $H=28.8 \mathrm{~h} / \mathrm{ha}$. At an average cost of about $€ 53.55 / \mathrm{h}$ milling unit PT-400 FAE 300/S, the average cost per ha is $€ 1,542.3 /$ ha.

For $\mathrm{C}_{4}$ clearings, operations No. 4, 5, 6 are carried out in accordance with Table 6 . The total relative costs for labor and machinery for site preparation of 1 ha is $H=29.3 \mathrm{~h} / \mathrm{ha}$. At an average price of $€ 53.55 / \mathrm{h}$ milling unit PT-400 and FAE 300/S, the average cost per ha site preparation is $€ 1,569.0 / \mathrm{h}$.

\subsection{Comparison of Three Technological Schemes}

The comparison of three technological schemes is shown in Table 8 and Figs. 2 and 3. From the results, it appears that the costs of machinery for site preparation per ha are the highest in $\mathrm{TS}_{1}$. The mechanized eradicating of $\mathrm{C}_{1}$ poplar clearings for 1 ha site preparation generally are required $95.1 \mathrm{~h}, 97.2 \mathrm{~h}$ for $\mathrm{C}_{2}, 105.8 \mathrm{~h}$ for $\mathrm{C}_{3}$ and $107.9 \mathrm{~h}$ for $\mathrm{C}_{4}$. At a price of $€ 30.6 / \mathrm{h}$ for $1 \mathrm{~h}$ of a tractor T-170 operation for $\mathrm{TS}_{1}$ and $\mathrm{TS}_{2}$, the average price per ha total site preparation in $\mathrm{TS}_{1}$ for $\mathrm{C}_{1}$ clearings is $€ 2,910.1 /$ ha, $€ 2,973.3 /$ ha for
$\mathrm{C}_{2}, € 3,237.5 /$ ha for $\mathrm{C}_{3}$ and $€ 3,301.7$ /ha for $\mathrm{C}_{4}$. It is good to notice that the qualitative and ecological indicators of site preparation in $\mathrm{TS}_{1}$ are one of the worst [20, 21].

Significantly lower, almost at half, are the costs for site preparation in $\mathrm{TS}_{2}$ (Figs. 2 and 3). For 1 ha site preparation in $\mathrm{C}_{1}$, poplar slash requires total amount of $40.2 \mathrm{~h}$ with the total price of $€ 1,230.1 / \mathrm{h}, 42.3 \mathrm{~h}$ with cost $€ 1,294.4 / \mathrm{ha}$ for $\mathrm{C}_{2}$ clearings, $50.9 \mathrm{~h}$ with $€ 1,557.5 / \mathrm{ha}$ for $\mathrm{C}_{3}$ and $53.0 \mathrm{~h}$ with $€ 1,621.8 / \mathrm{ha}$ for $\mathrm{C}_{4}$, respectively. It is good to emphasize that for this technology, the quality and ecology indicators for site preparation are better than for the first scheme.

The lowest costs of labor and machinery are gained by implementing $\mathrm{TS}_{3}$. The total relative costs per ha site preparation in $\mathrm{C}_{1}$ poplar clearings is $27.6 \mathrm{~h}, 27.9 \mathrm{~h}$ for $\mathrm{C}_{2}, 28.8 \mathrm{~h}$ for $\mathrm{C}_{3}$ and $29.3 \mathrm{~h}$ for $\mathrm{C}_{4}$. In addition, $\mathrm{TS}_{3}$ is distinguished by the highest quality and environmental performance $[20,21]$. Due to the relatively higher price, which is calculated for each hour of the milling unit PT-400, aggregated with FAE $300 / \mathrm{S}(€ 53.55 / \mathrm{h})$, under this scheme, the costs per ha site preparation of clearings is more than $\mathrm{TS}_{2}$ with $€ 248 /$ ha and $€ 200 /$ ha, respectively, for $C_{1}$ and $C_{2}$. This is higher than $\mathrm{TS}_{2}$, but is slightly lower that the costs for site preparation in $\mathrm{C}_{3}$ and $\mathrm{C}_{4}$ clearings, respectively, with $€ 15 /$ ha and $€ 52 /$ ha. Comparative price per ha site preparation between $\mathrm{TS}_{3}$ and $\mathrm{TS}_{2}$ for $\mathrm{C}_{1}$ clearings is $€ 1,478.0 / \mathrm{ha}$ against $€ 1,230.1 / \mathrm{ha}$, in favor of $\mathrm{TS}_{2}$ applied in $\mathrm{C}_{2}$ clearings. Then the ratio is

Table 6 Performance and expenditure of time by operations in $\mathrm{TS}_{3}$.

\begin{tabular}{|c|c|c|c|}
\hline No. & Technological operation & $\begin{array}{l}\text { Performance for a } \\
\text { shift (ha/shift) }\end{array}$ & $\begin{array}{l}\text { Cost of machinery } \\
\text { and labor }(\mathrm{h} / \mathrm{ha})\end{array}$ \\
\hline 1 & $\begin{array}{l}\text { Crushing standing vegetation (mulching) in } \mathrm{C}_{1} \text { clearings with forest milling unit } \\
\text { PT-400 with multipurpose tiller FAE } 300 / \mathrm{S}\end{array}$ & 1.905 & 4.2 \\
\hline 2 & $\begin{array}{l}\text { Crushing standing vegetation (mulching) in } \mathrm{C}_{2} \text { clearings with forest milling unit } \\
\text { PT- } 400\end{array}$ & 1.778 & 4.5 \\
\hline 3 & $\begin{array}{l}\text { Shredding of wood residues, brushes and standing vegetation (mulching) in } \mathrm{C}_{3} \\
\text { clearings, with forest milling unit PT- } 400\end{array}$ & 1.481 & 5.4 \\
\hline 4 & $\begin{array}{l}\text { Shredding of wood residues, brushes and standing vegetation (mulching) in } \mathrm{C}_{4} \\
\text { clearings, with forest milling unit PT- } 400\end{array}$ & 1.356 & 5.9 \\
\hline 5 & $\begin{array}{l}\text { Shredding stumps in clearings of all categories, with forest milling unit PT-400 } \\
\text { with multipurpose tiller FAE } 300 / \mathrm{S}\end{array}$ & 0.482 & 16.6 \\
\hline 6 & $\begin{array}{l}\text { Deep milling up to } 50 \mathrm{~cm} \text { with milling aggregator PT- } 400 \text { with forestry tiller FAE } \\
300 / \mathrm{S}\end{array}$ & 1.176 & 6.8 \\
\hline
\end{tabular}


Table 7 Manufacturing costs for site preparation of poplar clearings in $\mathrm{TS}_{3}$.

\begin{tabular}{lll}
\hline Category of poplar clearings & Summary relative cost of machinery and labor $(\mathrm{h} / \mathrm{ha})$ & Price per ha of site preparation $(€ / \text { ha })^{* *}$ \\
\hline $\mathrm{C}_{1}$ & 27.6 & $1,478.0$ \\
$\mathrm{C}_{2}$ & 27.9 & $1,494.1$ \\
$\mathrm{C}_{3}$ & 28.8 & $1,542.3$ \\
$\mathrm{C}_{4}$ & 29.3 & $1,569.0$ \\
\hline
\end{tabular}

${ }^{* *}$ The price of one hour of machine work includes all production costs, material costs (fuel and lubricants, maintenance, repair and spare parts, transport, etc.), salaries, insurances, maintenance, profit and others.

Table 8 Comparison of labor and machinery costs and prices for site preparation in four different technological schemes.

\begin{tabular}{|c|c|c|c|c|c|c|c|c|}
\hline \multirow{3}{*}{$\begin{array}{l}\text { Technological } \\
\text { schemes }\end{array}$} & \multicolumn{8}{|c|}{ Category of poplar clearings } \\
\hline & \multicolumn{2}{|c|}{$\mathrm{C}_{1}$} & \multicolumn{2}{|c|}{$\mathrm{C}_{2}$} & \multicolumn{2}{|c|}{$\mathrm{C}_{3}$} & \multicolumn{2}{|c|}{$\mathrm{C}_{4}$} \\
\hline & $\begin{array}{l}\text { Machine and } \\
\text { labor costs } \\
(\mathrm{h} / \mathrm{ha})\end{array}$ & $\begin{array}{l}\text { Price } \\
(€ / \text { ha })\end{array}$ & $\begin{array}{l}\text { Machine and } \\
\text { labor costs } \\
(\mathrm{h} / \mathrm{ha})\end{array}$ & $\begin{array}{l}\text { Price } \\
(€ / \text { ha })\end{array}$ & $\begin{array}{l}\text { Machine and } \\
\text { labor costs } \\
(\mathrm{h} / \mathrm{ha}) \\
\end{array}$ & $\begin{array}{l}\text { Price } \\
(€ / \text { ha })\end{array}$ & $\begin{array}{l}\text { Machine and } \\
\text { labor costs } \\
(\mathrm{h} / \mathrm{ha}) \\
\end{array}$ & Price $(€ /$ ha $)$ \\
\hline $\mathrm{TS}_{1}$ & 95.1 & $2,910.1$ & 97.2 & $2,973.3$ & 105.8 & $3,237.5$ & 107.9 & $3,301.7$ \\
\hline $\mathrm{TS}_{2}$ & 40.2 & $1,230.1$ & 42.3 & $1,294.4$ & 50.9 & $1,557.5$ & 53.0 & $1,621.8$ \\
\hline $\mathrm{TS}_{3}$ & 27.6 & $1,478.0$ & 27.9 & $1,494.1$ & 28.8 & $1,542.3$ & 29.3 & $1,569.0$ \\
\hline Project scheme & 24.2 & 993.0 & 24.5 & $1,009.1$ & 25.4 & $1,057.2$ & 25.9 & $1,084.0$ \\
\hline
\end{tabular}

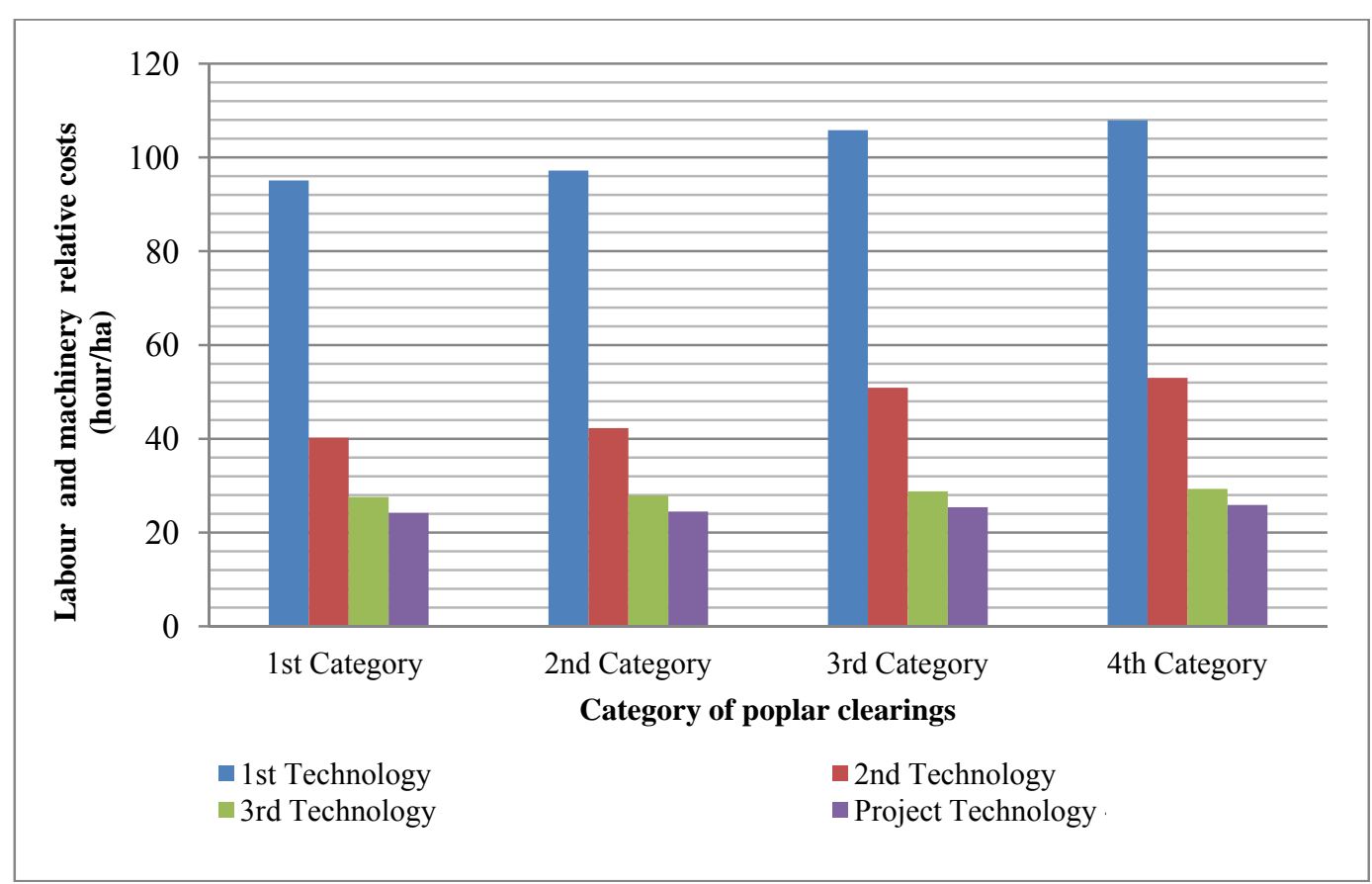

Fig. 2 Comparative diagram of machinery and labor costs for total site preparation at poplar clearings.

$€ 1,494.1 /$ ha against $€ 1,294.4 /$ ha. The things are different for $\mathrm{C}_{3}$ clearings, here there is a positive sign (€1,542.3/ha against $€ 1,557.5 /$ ha). For $\mathrm{C}_{4}$ clearings, the values are $€ 1,569 /$ ha against $€ 1,621.8 /$ ha (Table 8 and Fig. 3).

\subsection{Cost in Project Technological Scheme $\left(T S_{P}\right)$}

To enhance the economic performance of $\mathrm{TS}_{3}$ and to reduce the price per ha site preparation, while keeping its highest environmental and quality indicators, a new project technology is proposed for site preparation, which uses rotary eradicator for crushing the stumps. Thus, the system of machinery for site preparation will include two machines: rotary eradicator Rotor Speedy 130/160 and a milling unit PT-400 with multifunctional forestry tiller FAE 300/S. 


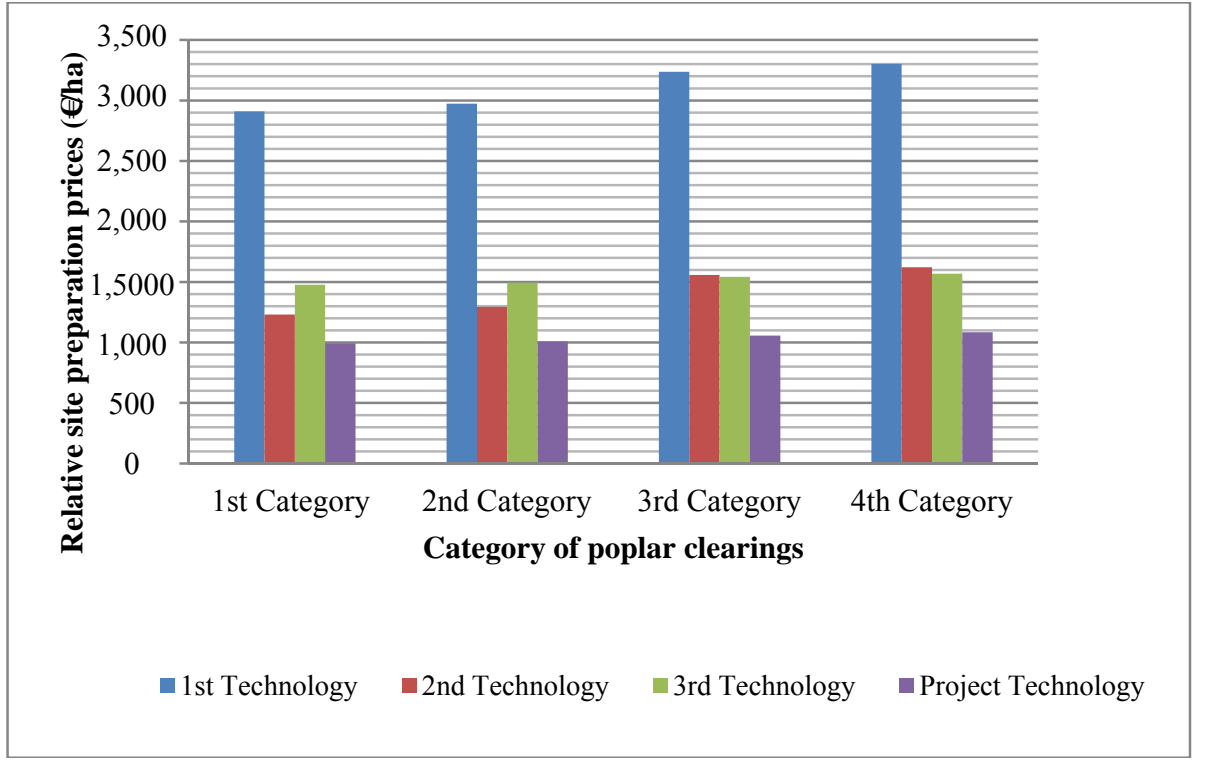

Fig. 3 Comparative diagram of relative prices for 1 ha total site preparation at poplar clearings.

Table 9 Performance and expenditure of time by operations for $\mathrm{TS}_{\mathrm{P}}$.

\begin{tabular}{|c|c|c|c|}
\hline No. & Technological operation & $\begin{array}{l}\text { Performance for a } \\
\text { shift (ha/shift) }\end{array}$ & $\begin{array}{l}\text { Cost of machinery } \\
\text { and labor }(\mathrm{h} / \mathrm{ha})\end{array}$ \\
\hline 1 & $\begin{array}{l}\text { Crushing low stand vegetation in } \mathrm{C}_{1} \text { clearings with milling unit PT- } 400 \text {, with } \\
\text { forestry tiller FAE } 300 / \mathrm{S}\end{array}$ & 1.905 & 4.2 \\
\hline 2 & $\begin{array}{l}\text { Crushing high stand vegetation in } \mathrm{C}_{2} \text { clearings with milling unit PT- } 400 \text {, with } \\
\text { forestry tiller FAE } 300 / \mathrm{S}\end{array}$ & 1.778 & 4.5 \\
\hline 3 & $\begin{array}{l}\text { Shredding of wood residues, brushes and standing vegetation in } \mathrm{C}_{3} \text { clearings, } \\
\text { with milling unit PT- } 400 \text {, with forestry tiller FAE } 300 / \mathrm{S} \text {; }\end{array}$ & 1.481 & 5.4 \\
\hline 4 & $\begin{array}{l}\text { Shredding of wood residues, brushes and standing vegetation in } \mathrm{C}_{4} \text { clearings, } \\
\text { with milling unit PT- } 400 \text {, with forestry tiller FAE } 300 / \mathrm{S} \text {; }\end{array}$ & 1.356 & 5.9 \\
\hline 5 & $\begin{array}{l}\text { Crushing stumps in all categories clearings with rotary eradicator Rotor Speedy } \\
130 / 160\end{array}$ & 0.608 & 13.2 \\
\hline 6 & $\begin{array}{l}\text { Deep milling up to } 50 \mathrm{~cm} \text { in all categories with milling unit PT-400, with } \\
\text { forestry tiller FAE } 300 / \mathrm{S}\end{array}$ & 1.176 & 6.8 \\
\hline
\end{tabular}

The operation of shredding stumps and roots will be done with rotary eradicator Rotor Speedy 130/160, powered by tractor New Holland TM-150. The operations of mulching wood residues, brushes and standing vegetation and primary tillage will be executed by milling aggregate PT-400 with forestry tiller FAE $300 / \mathrm{S}$. Depending on the category of the poplar clearings, the site preparation in this project technology contains the following operations and system machines:

(1) Shredding low stand vegetation in $\mathrm{C}_{1}$ clearings with forestry tiller FAE 300/S and PT-400;

(2) Shredding high stand vegetation and shrubs in slashes of $\mathrm{C}_{2}$ clearings with forest tiller FAE 300/S;

(3) Shredding of wood residues, brushes and low standing vegetation in $\mathrm{C}_{3}$ clearings forestry tiller FAE 300/S;

(4) Shredding of wood residues, brushes and standing vegetation in $\mathrm{C}_{4}$ clearings with multifunctional forestry tiller FAE $300 / \mathrm{S}$;

(5) Shredding stumps in all categories clearings with rotor eradicator Rotor Speedy 130/160 with tractor New Holland TM-150;

(6) Main soil cultivation after eradication in all categories clearings through deep milling up to $50 \mathrm{~cm}$, with a milling unit PT-400, with forest tiller FAE $300 / \mathrm{S}$.

The productivity and costs of labor and machines in separate operations for $\mathrm{TS}_{\mathrm{P}}$ are presented in Table 9. And total relative costs of labor and machinery, and 
average price (January-June 2016) per ha of mechanized site preparation of poplar clearings, applying $\mathrm{TS}_{\mathrm{P}}$, are provided in Table 10 .

For $\mathrm{C}_{1}$ clearings, operations No. 1, 5 and 6 , are carried out in accordance with Table 9. The total relative costs for labor and machinery for site preparation of 1 ha is $H=24.2 \mathrm{~h} / \mathrm{ha}$. At an average cost of about $€ 53.5 / \mathrm{h}$ for the operation of specialized milling unit PT-400 and $€ 30.6 / \mathrm{h}$ on a rotary eradicator Rotor Speedy with tractor New Holland TM-155, the average cost per ha site preparation is €993.0/ha.

For $\mathrm{C}_{2}$ clearings, operations No. 2, 5 and 6 are carried out in accordance with Table 9. The total relative costs for labor and machinery for site preparation of 1 ha is $H=24.5 \mathrm{~h} / \mathrm{ha}$. At an average cost of about $€ 53.55 / \mathrm{h}$ for work specialized milling unit PT-400 and $€ 30.6 / \mathrm{h}$ on a rotary eradicator Rotor Speedy with tractor New Holland TM-155, the average cost per ha site preparation is $€ 1,009.1 /$ ha.

For $\mathrm{C}_{3}$ clearings, operations No. 3, 5 and 6 are carried out in accordance with Table 9. The total relative costs for labor and machinery for site preparation of 1 ha is $H=25.4 \mathrm{~h} / \mathrm{ha}$. At an average cost of about $€ 53.55 / \mathrm{h}$ for the operation of specialized milling unit PT-400 and $€ 30.6 / \mathrm{h}$ on a rotary eradicator Rotor Speedy with Tractor New Holland TM-155, the average cost per ha site preparation is $€ 1,057.2 /$ ha.

For $\mathrm{C}_{4}$ clearings, operations No. 4,5 and 6 are carried out in accordance with Table 9. The total relative costs for labor and machinery for site preparation of 1 ha is $H=25.9 \mathrm{~h} / \mathrm{ha}$. At an average cost of about $€ 53.55 / \mathrm{h}$ for the operation of specialized milling unit PT-400 and $€ 30.6 / \mathrm{h}$ on a rotary eradicator
Rotor Speedy with tractor New Holland TM-155, the average cost per ha site preparation is $€ 1,084.0 /$ ha.

The relative costs of machinery and labor depending on the technological scheme for certain categories of clearings along the Danube River are shown in Table 8. Based on the obtained results, comparative charts for labor costs and machines (Fig. 2) and for prices (Fig. 3) are built for full site preparation of poplar clearings for afforestation with poplar plantations in different technological schemes.

By applying the specialized rotary eradicator "Rotor Speedy" for crushing stumps and roots in the project technology, it will reduce the costs for labor and machines with $3.4 \mathrm{~h} / \mathrm{ha}$, compared with that only used the milling unit PT-400, with forestry tiller FAE 300/S in $\mathrm{TS}_{3}$. This would have a significant impact on the average costs per ha site preparation. For example, if take the price of $1 \mathrm{~h}$ operating for these machines (€53.55/h for PT-400 with $300 \mathrm{FAE} / \mathrm{S}$ and $€ 30.6 / \mathrm{h}$ for Rotor Speedy), then the investment costs per ha site preparation for afforestation poplar plantations in $\mathrm{TS}_{\mathrm{P}}$ will be reduced to an average value of $€ 485 /$ ha. In the same time, the high quality and environmental performance of site preparation on the new technology is kept. Right away, after the site preparation in this technology, the soil will be ready for planting, without any further need of pre-sowing treatment, such as disking, milling or cultivation. Meanwhile, the entire biomass of lying and standing trees and bushes in the clearings will be crushed into chips and homogeneously mixed into the soil. Over the next few years, the biomass will decompose into valuable organic material and will improve the soil fertility and productivity of poplar plantations.

Table 10 Manufacturing costs for site preparation of poplar clearings for project technological scheme.

\begin{tabular}{lll}
\hline Category of poplar clearings & $\begin{array}{l}\text { Summary relative cost of machinery and labor } \\
(\mathrm{h} / \mathrm{ha})\end{array}$ & Price per ha of site preparation $(€ / \text { ha })^{* *}$ \\
\hline $\mathrm{C}_{1}$ & 24.2 & 993.0 \\
$\mathrm{C}_{2}$ & 24.5 & $1,009.1$ \\
$\mathrm{C}_{3}$ & 25.4 & $1,057.2$ \\
$\mathrm{C}_{4}$ & 25.9 & $1,084.0$ \\
\hline
\end{tabular}

The price of $1 \mathrm{~h}$ of machine work includes all production costs, material costs (fuel and lubricants, maintenance, repair and spare parts, transport, etc.), salaries, insurances, maintenance, profit and others. 


\section{Conclusions}

One significant portion of the capital expenses for poplar plantations establishment is concentrated in the first year. Most of this portion is invested in site preparation. In this work, the costs of labor and resources for implementing various technological schemes for site preparation along the Danube River in Bulgaria were studied. The oldest technology $\left(\mathrm{TS}_{1}\right)$ for cleaning the clearings from stumps, shrubs, clearing residues and stand vegetation are used universal bulldozers and front-tooth eradicators. Main disadvantages of this system of machines are lower environmental performance, longer deadlines for work and high labor and machinery costs. Significantly better results are obtained using $\mathrm{TS}_{2}$ by eradication of stumps with rotary eradicators. In this technology, the quality of work is high and the costs are half lower. To establish the costs for site preparation in the third and newest technology for Bulgaria for site preparation $\left(\mathrm{TS}_{3}\right)$, applied since the last two years, was conducted experimental research on the work of forestry tiller FAE 300/S, driven by prime mover PT-400. From the study, it was found that this technology has better quality and environmental performance and lower labor costs (reduction of about $31 \%-32 \%$ ). For the different clearings categories, the expenses for labor and machinery, measured in $\mathrm{h} / \mathrm{ha}$ site preparation vary from $24.2 \mathrm{~h} / \mathrm{h}$ a to $25.9 \mathrm{~h} / \mathrm{ha}$. The prices for site preparation of clearings from $\mathrm{C}_{3}$ and $\mathrm{C}_{4}$ in $\mathrm{TS}_{3}$ are almost comparable to these from $\mathrm{TS}_{2}$. The comparative analysis between the three technological schemes showed that the best quality indicators for site preparation are produced applying $\mathrm{TS}_{3}$. It ensures the lowest costs of labor and machinery, but due to the relatively high cost of maintenance of the milling unit PT-400 and FAE 300/S-225, the price per ha site preparation for clearings of $\mathrm{C}_{1}$ and $\mathrm{C}_{2}$ is higher with $€ 248 /$ ha to $€ 200 /$ ha, respectively. In order to ensure better quality, ecological and economic indicators of this technology, but timely to decrease final price per ha, it is proposed a new project technology $\left(\mathrm{TS}_{\mathrm{P}}\right)$. In
$\mathrm{TS}_{\mathrm{P}}$, shredding the stumps and roots will be performed by rotary eradicator Rotor Speedy $130 / 160$, powered by universal tractor, with power $90-120 \mathrm{~kW}$. Thus, according to the category of the poplar clearings, the relative costs for labor will vary from $14.2 \mathrm{~h} / \mathrm{ha}$ to $15.9 \mathrm{~h} / \mathrm{ha}$, and the final prices from $€ 993 / \mathrm{ha}$ to $€ 1,084$ /ha. Compared to $\mathrm{tS}_{3}$, the costs from $\mathrm{TS}_{\mathrm{P}}$ are lower with $12.3 \%$ and the price with $32.8 \%$.

The results of this study can be used for costs and resources planning when applying forest machinery for site preparation of poplar plantations establishment.

\section{References}

[1] Böhlenius, H., and Övergaard, R. 2015. "Exploration of Optimal Agricultural Practices and Seedling Types for Establishing Poplar Plantations." Forests 6 (8): 2785-98.

[2] Christersson, L. 2008. "Poplar Plantations for Paper and Energy in the South of Sweden." Biomass and Bioenergy 32 (11): 997-1000.

[3] Christersson, L. 2010. "Wood Production Potential in Poplar Plantations in Sweden." Biomass and Bioenergy 34 (9): 1289-99.

[4] Isebrands, J. G. 2007. "Best Management Practices Poplar Manual for Agroforestry Applications in Minnesota." University of Minnesota. Accessed September, 2007. http://www.extension.umn.edu/ environment/agroforestry/best-management-practices-po plar-manual/docs/00095full.pdf.

[5] Dimitrov, S., and Panov, P. 1982. Industrial Forest Plantations. Sofia, Bulgaria: Ministry of Forests and Forest Industry. (in Bulgarian)

[6] Gönna, V., and Marc, A. 1992. Fundamentals of Mechanical Site Preparation. FRDA Report 178, Government of Canada, British Columbia.

[7] Hansen, E., Netzer, D., and Rietveld, W. J. 1984. Site Preparation for Intensively Cultured Hybrid Poplar Plantations. St. Paul, MN: U.S. Department of Agriculture, Forest Service, North Central Forest Experiment Station.

[8] Marinov, K. 2013. Mechanization of Forest Operations. Sofia: Publishing House of University of Forestry. (in Bulgarian)

[9] Dilov, S. 2002. "Analysis Technology for Creating and Growing Poplar Plantations in SF Pleven." M.Sc. thesis, Higher Institute of Forestry, Sofia. (in Bulgarian)

[10] Löf, M., Dey, D. C., Navarro, R. M., and Jacobs, D. F. 2012. "Mechanical Site Preparation for Forest 

Establishment by Various Technological Schemes

Restoration." New Forests 43 (5-6): 825-48.

[11] Marinov, K., and Jordanova, V. 2015. "Evaluation of Forest Milling Machine Performances for Site Preparation." Innovation in Woodworking Industry and Engineering Design 4 (8): 18-29.

[12] Rocky Mountain Research Station USDA Forest Service. 2004. "Economic Uses Fact Sheet 01: Mastication Treatments and Costs." Fuels Planning: Science Synthesis and Integration, RMRS-RN-20-1, USDA Forest Service, Rocky Mountain Research Station.

[13] Keča, L., Keča, N., and Pajid, S. 2011. "Investment Appraisal of Poplar Plantations in Serbia." Baltic Forestry 17 (2): 268-79.

[14] Keča, L., and Pajić, S. 2015. "Costs and Revenues in Poplar Plantations Established Using Full Ground and Soil Preparation in Serbia." In Proceedings of International Conference Reforestation Challenges, 234-41.

[15] FAE Group. 2016. "Forestry Tiller FAE-300/S for Hydraulic Carriers PT-400.” Accessed January, 2016. http://www. fae-group.com/en.

[16] Hallbrook, J., Han, H., Graham, R., Jain, T., and Denner, R. 2006. "Mastication: A Fuel Reduction and Site
Preparation Alternative." In Proceedings of the 29th Council on Forest Engineering Conference, 137-46.

[17] Marinov, K. 2014. "Performance Characteristics Milling Units for Soil Preparation of Non-renewable Forest Areas." Management and Sustainable Development 49 (6): 113-20. (in Bulgarian)

[18] Jordanova, V., and Marinov, K. 2015. "Study of Milling Technology Unit Performance for Site Preparation of Forest Area for Afforestation." Forestry Ideas 21 (2): 335-46.

[19] Raykov, R., Stefanov, A., Milev, M., Petrova, R., Petkova, K., Dobrichov, I., Poryazov, Y., Yakimov, M., Kalmukov, K., Broshtilov, K., Nalbantov, G., Terziyski, T., and Stoykov, S. 2011. "Classification Scheme of Forest Site Types in Bulgaria.” Executive Forest Agency. Accessed 2011. http://www.iag.bg/data/docs/Shema.pdf. (in Bulgarian)

[20] Stoyanov, N. 1994. Organization and Planning in Forestry. Sofia: Zemizdat. (In Bulgarian).

[21] Bulgaria Forestry Committee. 2004. Employment Rates and Freight Rates for Afforestation Work. (in Bulgarian)

[22] Bulgaria State Forestry Agency. 2008. Departmental Labor Standards for Silvicultural Activities. (in Bulgarian) 